\section{Rediscovering Pluripotency: from Teratocarcinomas to Embryonic Stem Cells}

\author{
Cardiff, 10-12 October 2011
}

The pluripotent potential of embryonic stem cells has often seen them touted as the future of regenerative medicine. The road to any therapeutic success however, must stretch back to teratocarcinoma, the tumour from which pluripotent stem cells (embryonal carcinoma cells) were first derived. This 2011 meeting in Cardiff acted as a historical perspective from which the impact of embryonal carcinoma cell research on the present pluripotent stem cell landscape could be observed, with many of the early luminaries in this field still very active. The meeting addressed the genetic and epigenetic make-up of pluripotent stem cells, the mechanisms which control their fate, and their relationship to the early embryo proper. With each speaker tasked with revisiting previous questions, this meeting demonstrated how far has been travelled, yet how far is left to go.

\section{Introduction}

Those who cannot remember the past are condemned to repeat it.

\section{George Santayana, Reason in Common Sense}

The field of pluripotent stem cell research is furiously progressive, driven by investigators pursuing the latest discoveries and technologies, and a general public excited by its therapeutic benefits. However, whilst travelling forward one must also be able to look back, charting the earliest steps of the journey to ensure the best route ahead. With this philosophy in mind, researchers gathered at the National museum in Cardiff and plotted the scientific trajectory from a rare developmental tumour, known as teratocarcinoma, to one of the today's most exciting and vibrant research areas. A retrospective appraisal of the ideas offered an opportunity to revisit some of the remaining open questions and consider them in the light of the recent technological advances; an opportunity to build on lessons from the past in order to articulate nascent questions in the field.

\section{Teratoma: the little tumour that could}

Teratocarcinoma is classified as a germ cell tumour (GCT), with testicular GCT (TGCT) being the most common malignancy in young men (Rajpert-De Meyts, 2006). These tumours are typically a chaotic array of somatic tissues, composed of elements from all

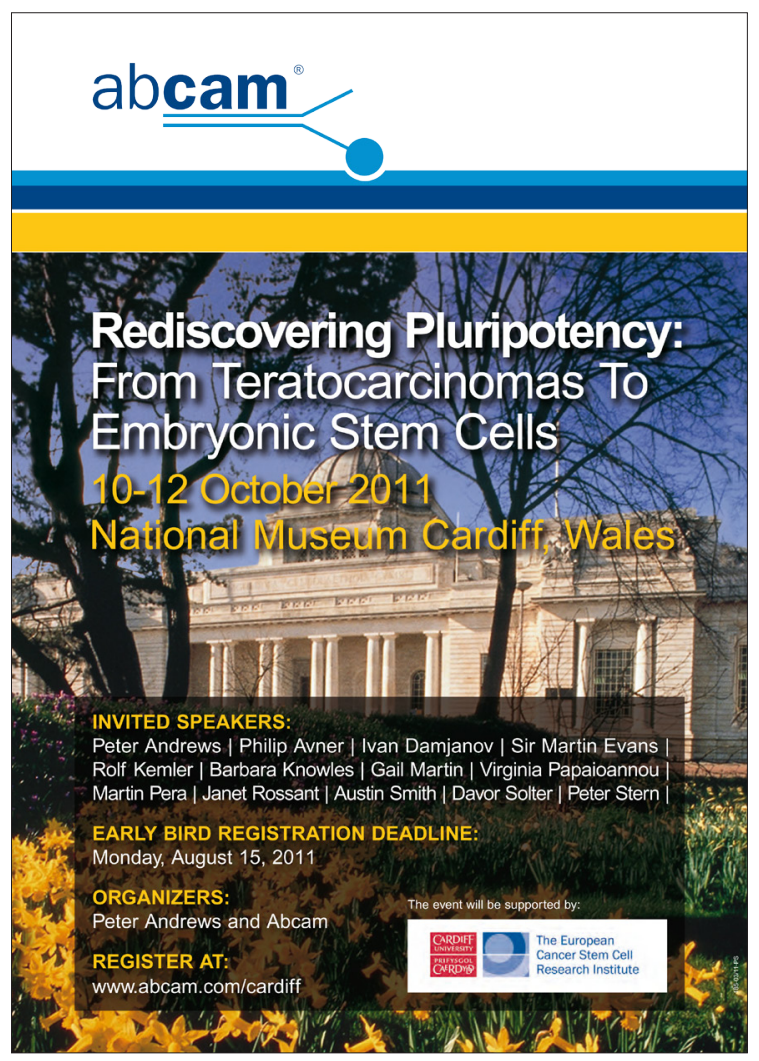

three embryonic germ layers. However, the crucial aspect of this tumour is that it also contains undifferentiated, malignant cells. The presence of malignant cells, known as embryonal carcinoma (EC), separates teratocarcinoma from teratoma which is benign and composed only of differentiated tissues (Andrews, 2002; Damjanov and Andrews, 2007). Although hugely influential as the originator of todays' pluripotent cell research, teratocarcinoma and GCT research still provide insight into both development and oncogenesis, highlighted in Ivan Damjanov's (University of Kansas, USA) lecture on 'Teratoma: the little tumour that could'.

For any cancer, defining and understanding the cell of origin can provide crucial insight into the oncogenic process, and in the case of teratoma/teratocarcinoma the cell of origin is undoubtedly a germ cell. In the ovaries, teratomas most likely arise from oocytes that develop parthenogenetically, with direct evidence for this provided in the inbred LT strain of mice described by Stevens and Varnum (1974) (Stevens and Varnum, 1974). For TCGT, it is

Abbreviations used in this paper: EB, embryoid body; EC, embryonal carcinoma; EGC, embryonic germ cell; EpiSC, epiblast stem cell; ES, embryonic stem; GCT, germ cell tumor; iPS, induced pluripotent stem; TGCT, testicular germ cell tumor.

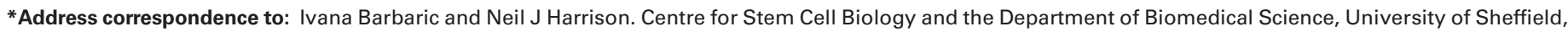
Western Bank, Sheffield, UK. S10 2TN. e-mail: i.barbaric@sheffield.ac.uk ; N.J.Harrison@sheffield.ac.uk
} 
unclear whether the transforming event occurs in a primordial germ cell or fetal gonocyte, though the nature of the event is generally accepted to involve an aberration(s) in differentiation (Rajpert-De Meyts, 2006). The development of TGCT then progresses through a carcinoma in situ (CIS) stage (Skakkebaek, 1972) before the tumour is recognised as either seminoma or non-seminoma. Seminoma is typically homogeneous, resembling primordial germ cells, whereas non-seminoma comprises teratocarcinoma, choriocarcinoma and yolk-sac tumours though it should be noted that tumours containing a mixture of all these elements may often be found (Oosterhuis and Looijenga, 2005). Clearly, teratomas and teratocarcinomas presented a research opportunity, though exploiting this was made difficult by the low incidence of animal models. Indeed, the work of Fawcett in 1950 described only one teratoma in 22,000 female mouse autopsies (Fawcett, 1950). This paucity of material was alleviated by the pioneering work of Stevens, who in 1954 described that strain 129 mice were predisposed to testicular teratoma formation (Stevens and Little, 1954). This work was particularly remarkable given that no spontaneous testicular teratomas had been previously reported in any mouse strain. The tumours in strain 129 mice comprised a variety of differentiated tissue, though undifferentiated, EC cells were rarely seen. This observation likely explains why most TGCT from these mice are benign, and made Ivan Damjanov question the relevance of this model for the human conditions, in which malignant teratocarcinoma is the norm.

However, despite the low incidence of EC cells, transplantable teratocarcinoma could be maintained. These tumours were maintained within strain 129 mice, from which ascitic fluid containing aggregated structures known as embryoid bodies (EB) could be isolated. EB contained differentiated tissue, and are still used routinely for differentiation of ES cells today, though the EB in this ascitic fluid also contained EC cells. These EC cells were shown to be pluripotent through xenograft studies, though the question remained whether this property belonged to single EC cells, or the population as a whole. This question was answered by Pierce and Kleinsmith in 1964, in a seminal experiment highlighted by several speakers (Kleinsmith and Pierce, 1964). Pierce and Kleinsmith were able to take single EC cells from teratocarcinoma-derived $\mathrm{EB}$, transplant them into mice, and regenerate a teratocarcinoma comprising the differentiated and undifferentiated cell types observed in the original tumour. This demonstrated unequivocally that each EC cell had the intrinsic capacity for multipotent differentiation and self-renewal, and provided perhaps the first example of a 'cancer stem cell' in a solid tumour. However, this also provided a further oncogenic conundrum - why, during cancer progression, would a tumour give rise to differentiated derivatives that are benign?

The tumorigenic potential of pluripotent cells is obviously a key consideration if they are to reach the clinic for uses in regenerative medicine, and this issue has been brought sharply into focus by numerous reports demonstrating genetic instability in human ES and induced pluripotent stem (iPS) cells (Baker et al., 2007; Gore et al., 2011; Mayshar et al., 2010). That the changes most frequently observed in ES cells are also commonly found in EC cells, and that the abnormal cells tend to give rise to teratocarcinomas in mouse models, is clearly a cause for concern (Baker et al., 2007). With this in mind, there is much value in developing assays to test the malignant potential of ES cells, and Ivan
Damjanov believed histologists have a key role to play. Here, the standardisation of xenografting and xenograft interpretation could provide a routine test of developmental and oncogenic potential.

\section{Teratomas and chimeras}

As the sixties swung to their conclusion, further methods for teratoma/teratocarcinoma formation were reported. Again, the research of Stevens proved prominent as he was able to demonstrate teratocarcinoma development from (i) grafting of the genital ridge of E12.5 mouse embryos into adult testis in strain 129 mice (Stevens, 1967); (ii) implanting early mouse embryos into extrauterine adult sites (Solter et al., 1970; Stevens, 1968); (iii) parthogenetic activation of oocytes in strain LT mice (Stevens and Varnum, 1974). Of these approaches, the induction of tumour formation by implanting normal mouse embryos proved attractive to Davor Solter (IMB, A*STAR, Singapore), who shared his finding in the second lecture of the meeting.

Professor Solter noted that of the embryo-derived tumours, approximately half were teratoma and half teratocarcinoma, and set out to investigate which factors could affect this balance. The first variable investigated was the age of the embryo transplanted, which revealed that 7.5 days was the strict cut-off for teratocarcinoma formation. Intriguingly, this is too late for the generation of mouse ES cells, suggesting differences between mouse ES and EC cells that would be touched upon by other speakers. The section of the embryo transplanted was the next variable, and here it was found that, for the 7.5 day embryo, only the embryonic portion of the egg cylinder was able to give rise to teratocarcinoma. The extraembryonic portion of the embryo was unable to form teratoma or teratocarcinoma, further confirming the embryonic region as the stem cell residence.

The final variable to be scrutinised was the mouse strain used. It was known that, from syngeneic grafts, there were marked differences in the incidence of teratocarcinoma between different mouse strains, with e.g. $75 \%$ of the tumours in strain Balb/c mice scored as teratocarcinoma compared to $5 \%$ in stain AKR. By transplanting embryos across different strains however, it was noted that it was the host, rather than the grafted embryo, that impacted most strongly on teratocarcinoma formation. Here, by grafting strain AKR embryos onto AKR $\times$ C57BL/6 hosts, teratocarcinoma incidence increased to $84 \%$. These data suggested that an immune response was necessary for efficient embryo-derived teratocarcinoma, supported by the decreased incidence of malignant tumours when host mice were immune compromised by cyclophosphamide or $\mathrm{X}$-irradiation treatment prior to engraftment. This body of work also suggests there is an intrinsic malignancy associated with the normal mouse embryo, which should not be overlooked should human ES cells be derived which resemble more closely those from mouse.

The embryo-engraftment performed by Davor Solter could be construed as creating a chimeric animal, though for those in the stem cell community this term is typically applied to an organism created by injecting cells from one individual into a genetically distinct blastocyst. Today, this assay is considered the strictest test of pluripotency, satisfied only when a stem cell can form a chimeric animal and contribute to all 3 somatic germ layers in addition to the germ cells themselves. However, the origins of the assay can be dated back the 1960's, the same time period during which teratocarcinomic research was beginning to boom, and this was the 


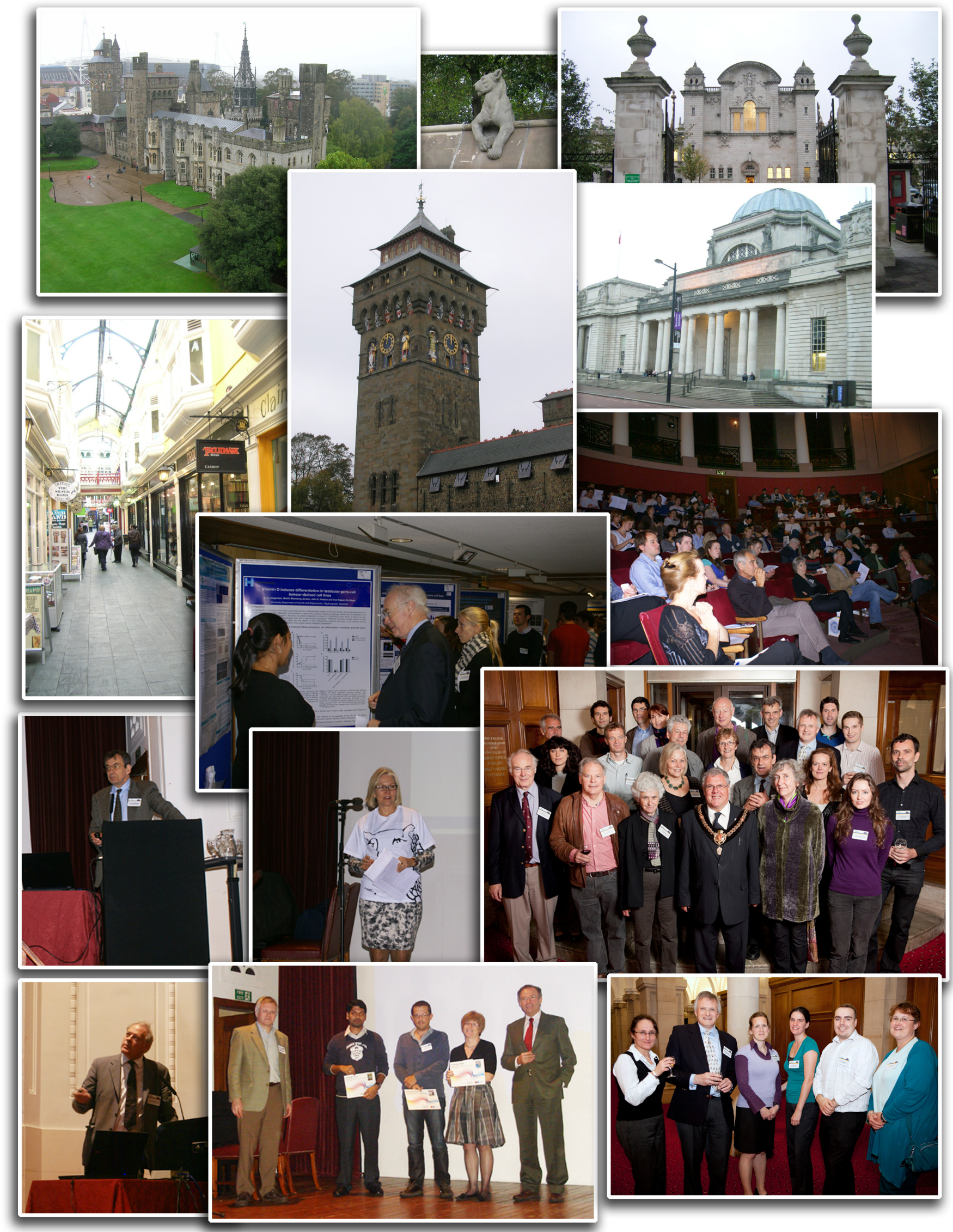


focus of Virginia Papaioannou (Columbia University, USA) lecture.

Fitting with the historical perspective of the meeting Prof. $\mathrm{Pa}-$ paioannou paid credit to the pioneering work of Tarkowski (1961) (Tarkowski, 1961) and Mintz (1962) (Mintz, 1962), who paved the way for Gardner's seminal experiments which demonstrated chimeric mice could be generated by injection of embryonic cells into the blastocyst (Gardner, 1968). By marking these cells, early developmental processes such as embryo regulation, $\mathrm{X}$-inactivation and cell fate could be studied, and one could answer the timeless question as to which cells in the embryo were truly pluripotent. For Prof. Papaioannou and others, this technique also provided a tool to address questions regarding the developmental capability, and tumorigenicity of teratocarcinoma and EC cells. The creation of chimeric mice using teratocarcinoma cells was demonstrated by Brinster, who injected dissociated EB from ascites into a blastocyst and found they could participate in embryonic development. In this report no tumours were found in the chimeric mice, suggesting that the inner working of the embryo had silenced the malignant machinery of the injected cells (Brinster, 1974). However, it was noted that the chimeric contribution was reduced when compared to that of embryonic cells, a result later confirmed by other groups. Further, EC cells maintained in culture tended to give rise to abnormal chimeras, in which tumours developed, and these cells were unable to contribute towards the germ line. Here then, the differences inherent between mouse ES and EC cells were again highlighted.

\section{Understanding embryonal carcinoma (EC) cells - a cultured approach}

As the differences between pluripotent cells of the normal mouse embryo EC cells and of mouse teratocarcinoma became more apparent, it was obvious that genuine mouse ES cells would need to be generated. This breakthrough was made possible by meticulous studies of EC cells in culture, which were reviewed with great humility by Gail Martin (UCSF, USA) and Sir Martin Evans (Cardiff University, UK).

As mentioned, EC cells could be extracted from the ascites of mice with teratocarcinoma, and EC cell lines were derived using this method (Jakob et al., 1973; Kahan and Ephrussi, 1970; Rosenthal et al., 1970). These EC cell lines were mostly homogeneous, made up of only undifferentiated, malignant cells. The key aspect of Martin and Evans work was to derive EC cell lines from solid tumours, and to interrogate not only the different cell types emerging, but also their relationship. The first in vitro lines generated from solid tumours were from embryo-induced teratocarcinoma, and derived onto X-irradiated chick fibroblasts (Evans, 1972). All lines derived in this manner were heterogeneous in primary culture, though they contained islands of tightly packed cells, which Prof. Evans was able to clone out as lines. Of the lines derived, the SIKR line was chosen for further study based on good in vitro growth, and in vivo differentiation. From subcloning this line it was noted that two distinct cell types were present, termed $C$ cells (tightly packed cells, which were later recognised as EC cells) and E cells, with an epithelial-like morphology. On injection of the $C$ cells into mice, differentiated tumours were observed, yet the $E$ type cells did not give tumours, suggesting it was the $\mathrm{C}$ cells that were pluripotent, malignant cells. When the subcloned lines were maintained in culture, the $\mathrm{C}$ cells could be maintained as a homogenous popu- lation when grown in the presence of feeder cells (either STO or chick fibroblasts), yet when plated without feeders a mixed culture of $C$ and $E$ cells would be generated. By contrast, $E$ cells could be maintained by themselves, and despite in vitro transformation, would only give rise to E cell containing tumours. These data led Martin and Evans to hypothesize that the $\mathrm{C}$ cells gave rise to $\mathrm{E}$ cells, and that the fibroblast-like $\mathrm{E}$ cells acted as feeder cells for the $\mathrm{C} /$ EC cells (Martin and Evans, 1974; Martin and Evans, 1975). Thus, aware of the importance of the supportive feeder layer in deriving EC cells, Martin and Evans were able to derive mouse ES cells.

\section{From embryonal carcinoma (EC) cells to embryonic stem (ES) cells and beyond}

The first embryo derived pluripotent cells were isolated independently in 1981 by Martin Evans and Matt Kauffman from delayed blastocysts of 129 strain of mice (Evans and Kaufman, 1981), and by Gail Martin, using medium conditioned by embryonic carcinoma cells (Martin, 1981). The availability of mouse ES cells coupled with gene targeting and germline transmission, transformed the landscape of mammalian biology as it provided a genetic toolkit for studying development and disease in the mouse as a model organism. In 2007 Sir Martin Evans, Oliver Smithies and Mario Capecchi were awarded the Nobel Prize in Physiology or Medicine for their contributions in this area.

Although the use of mouse ES cells became universal, the emphasis was on using them as a tool, and the biology of these remarkable cells remained the focus of interest for only a small number of researchers. It was another 17 years before James Thomson was successfully able to derive ES cells from human blastocysts (Thomson et al., 1998), inspiring visions that these cells could be used for regenerative medicine, and fueling intense research efforts to uncover the mechanisms underlying stem cell fate and the ways to control it. But the therapeutic potential of human ES cells was not the only reason for the passionate interest of the public and media in ES cells - controversies regarding the ethical acceptability of destroying a human blastocysts during the process of ES cell derivation has dominated the field since its inception. The advent of iPS cells has been hailed as an ethical alternative to ES cells (Takahashi et al., 2007). In her talk "Pluripotency: iPS cells and the shaping of stem cell science", Christine Hauskeller (University of Exeter, UK) presented findings of the study in which stem cell scientists working in two distinct socio-political backgrounds - Germany and the UK - were interviewed shortly after the derivation of human iPS cells. To the audience of stem cell scientists it was perhaps not surprising that interviewees hailed iPS cells as a "breakthrough" but at the same time highlighted importance of continuing research on human ES cells which are the precedents of iPS cells and offer a reference or a standard for comparison. Unfortunately, many of the policymakers still seem to question legitimacy of human ES cell research. Indeed, only a few days after the Cardiff meeting, on the $18^{\text {th }}$ October 2011, the Court of Justice of the European Union announced its decision that procedures involving human embryonic stem cells cannot be patented. Ramifications of this decision on investment and funding of ES cell research in Europe remain to be seen, but we are reminded yet again that in this field perhaps more than in any other, we can expect interference of politics in the progress of research.

Apart from offering a seemingly less ethically questionable 
source of pluripotent cells, iPS cells opened up new avenues of modeling human diseases, amenable even in cases where the underlying causative effects of a disease are unknown. Complex diseases such as cancers that involve genetic and epigenetic changes can also be probed by using iPS cell technology, in order to assess the relative contributions of these factors to the disease. In this context, Steven Pollard (UCL, UK) presented his work on reprogramming highly malignant, aneuploid human glioblastoma cells. Reprogramming of glioblastoma neural stem cells was achieved by using just two transcription factors: OCT4 and KLF4. Reprogrammed glioblastoma iPS cells (GiPSCs) expressed ES-like transcriptome whereas methylation patterns were globally reconfigured, including demethylation of OCT4 and NANOG promoters as well as re-activation of tumor supressors. Importantly, epigenetic reprogramming allowed GiPSCs to differentiate into non-neural cells in vitro and in vivo. It remains to be seen whether rescuing all the epigenome defects would render the cells with the same genome less malignant.

Another type of pluripotent stem cells are embryonic germ (EG) cells derived from primordial germ cells. In vivo, primordial germ cells are unipotent embryonic precursors of either sperm or eggs. However, when placed under appropriate culture conditions, primordial germ cells can give rise to ES-like cells termed EG cells, which contribute to chimera formation (Matsui et al., 1992). Difficulties in deriving EG cells presented a major obstacle in understanding how unipotent primordial germ cells convert to pluripotent EG cells. Towards answering the questions whether the ability to convert to EG cells is a general property of primordial germ cells, and in which species this could be achieved, Harry Leitch (University of Cambridge, UK) presented evidence that $2 \mathrm{i}$ media (the MEK inhibitor PD0325901 and the GSK3 inhibitor CHIR99021) in combination with LIF allows efficient derivation of mouse EG cells. EG cells derived under 2i/LIF contribute to chimera formation and are germline competent. Application of the same conditions also proved fruitful in deriving the first rat EG cells (Leitch et al., 2010).

\section{Characterisation of pluripotent cells}

Cell surface molecules - With a host of pluri/multipotent stem cell lines generated, one of the key challenges is effective characterisation. This sentiment is as true now as when the original EC cell lines were created, though many of the tools now used routinely in pluripotent stem cell laboratories owe much to the early pioneers in this field.

The lecture given by Peter Andrews (University of Sheffield, UK), who generated the TRA-series of antibodies, covered much of the work involved in identifying cell surface antigens on pluripotent cells. The original impetus was provided by the work of Artz et al., (1973), who, by immunizing syngeneic mice with the F9 murine teratocarcinoma line, generated antiserum to the F9-antigen. Subsequent studies detected this antigen on germ cells and EC cells of both mouse and human (Holden et al., 1977), suggesting some comforting conservation across different mammalian species. The drawback to the antisera however, was that they were variably able to react with a number of antigenic determinants, making difficult the identification of specific antigens associated with embryonic development. Fortunately for the field, however, the search for embryonic antigens coincided with the development of monoclonal antibody technology, which was utilised to create antibodies that reacted specifically with undifferentiated cells. At similar times, Stern and colleagues published data on the anti-Thy1 and Forsmann series of antibodies (Stern et al., 1975; Stern et al., 1978), whilst Knowles and Solter published data pertaining to an antibody which recognised a stage specific embryonic antigen (SSEA1) (Solter and Knowles, 1978). SSEA1 was shown to be expressed on cells of the 2 cell - ICM mouse embryo, mouse EC cells, and later on mouse ES cells. However, despite initial hopes of conservation, this antigen was not expressed in similar stage human embryos, or by human ES or EC cells. Indeed, SSEA1 is only expressed by human ES and EC cells which are undergoing differentiation. For undifferentiated human cells, the key antigens appear to be SSEA3 and SSEA4 (glycolipids like SSEA1), and the TRA series (TRA-1-60, TRA-1-81, TRA-2-49 and TRA-2-54) (Draper et al., 2002), though recent antigens described by Wright et al., (2011) and SSEA5 (Tang et al., 2011) may also prove valuable. That SSEA1 and SSEA3/4 show opposed expression in mouse ICM and ES cells compared to human ICM and ES cells further demonstrates the speciation differences that the field must consider.

The relative specificity of these antigens to embryonic tissue, and the energy devoted to generating their complex biochemical structures, suggests they should play an important role in development. However, one of the conundrums raised by Prof. Andrews is that the SSEA- and TRA- antigens are not required for embryo, ES or EC cell growth. Whilst the presence of certain cell surface antigens remains puzzling, the role of other membrane molecules is being clarified. This was evident in the lecture given by Rolf Kemler (MPI, Germany), who charted a path from the cell surface to cell senescence. Although initially intrigued by the F9-antigen, the uvomorulin molecule provided a major focus for Prof. Kemler. Studies from the 1980's had demonstrated the importance of this protein, better known now as E-cadherin, in compaction of the 8 cell embryo (Johnson et al., 1986). More recent work revealed E-cadherin was also involved in the maintenance of mouse ES cells in vitro, which became LIF-independent when this protein was knocked out (Soncin et al., 2009). By re-expressing variant forms of E-cadherin LIF-dependence could be regained, but only when the re-expressed $\mathrm{E}$-cadherin contained a $\beta$-catenin binding domain (Soncin et al., 2009). Hence, it appeared that differentiation of ES cells in the absence of LIF was dependent of E-cadherin$\beta$-catenin signalling. With the focus now shifted onto $\beta$-catenin, the story took a further twist, with a network established between $\beta$-catenin and TERT.

In $\beta$-catenin knockout ES cells, both TERT expression and telomere length were significantly reduced. Conversely, when an ES line was created with a stabilised form of $\beta$-catenin, TERT expression increased. Prof. Kemler was able to show that $\beta$-catenin and Klf4 act together to regulate TERT expression, with Klf4 alone unable to elicit TERT expression even when bound to the promoter. That TERT has previously been shown to modulate the Wnt pathway (Park et al., 2009) demonstrates cross-talk between these pathways, though the work described here was the first time that this relationship had been investigated in ES cells. Whether a similar system exists in human is still to be determined, though the positive effects of Wnt signalling on proliferation and survival in human ES cells suggests merit in such a model.

Another molecule influenced by E-cadherin is the cell surface antigen 5T4, which was the focus of Peter Stern's (Paterson Institute, UK) lecture. E-cadherin prevents surface expression of 5T4, and 
as such 5 T4 is only seen when ES cells down-regulate E-cadherin during differentiation. This down-regulation of E-cadherin, in addition to a number of other changes (e.g. up-regulation of vimentin, slug, snail) are strongly associated with epithelial-mesenchymal transition (EMT), a key event in both embryonic development and cancer (Mani et al., 2008). Indeed, the data presented re-iterated the intertwined nature of these two areas, and the theme of the meeting.

In relation to cancer EMT has been implicated in metastasis, creating a phenotype suited to motility. Exploiting ES cell differentiation as a model of EMT, Prof. Stern revealed up-regulation of chemokine CXCL12, which can influence chemotactic cell migration. CXCL12 acts through CXCR4, which can only reach the cell surface when 5 T4 is expressed. Thus, by targeting 5 T4, it may be possible to prevent CXCL12 mediated metastasis, with positive data already collected for B-ALL tumours. Further, since 5T4 is over-expressed in a number of carcinomas, Prof. Stern believed this molecule may act as a genuine target for immunotherapy.

Cell signalling - Understanding the molecular cues that specify the stem cell fate is a prerequisite in our pursuit to control the stem cell behavior. Austin Smith (University of Cambridge, UK) has been at the forefront of establishing important principles of signaling pathways governing mouse ES cell fate decisions. In his talk, Professor Smith recounted the remarkable journey that led him to identify a factor in conditioned media prepared from Buffalo rat liver cells that could sustain self-renewal of mouse ES cells in the absence of feeders (Smith et al., 1988). Initially termed Differentiation Inhibiting Activity (DIA), this cytokine is now widely known as Leukemia Inhibitory Factor (LIF). The use of LIF and BMP4 allowed defined, serum-free culture conditions of mouse ES cells (Ying et al., 2003). However, these conditions did not solve a problem of low efficiency of ES cell derivation from nonpermissive mouse strains (mouse strains other than 129). This has been achieved more recently by using media supplemented with two small inhibitors-PD0325901 (MEK inhibitor) and CHIR99021 (GSK3 inhibitor) (Ying et al., 2008). The 2i media keeps mouse ES cells in a more homogeneous state in culture compared to the serum conditions. Thus, Prof. Smith postulated that the 2 i conditions keep mouse ES cells in a state equivalent to the epiblast cells of the preimplantation blastocyst - the ground state of pluripotency. The ground state postulate defines naïve pluripotency as the basal cellular state in which: (i) the cells are autonomously self-replicating, (ii) vulnerable to extrinsic perturbation (Erk), (iii) epigenetically unprogrammed (reactivated $\mathrm{X}$-chromosome) and (iv) commanded by transcription factors (Nanog/Oct4/Sox2/Klfs/Esrrb/Stat3). The RNAsequencing and ChiP sequencing analyses revealed that the ground state ES cells have a distinctive transcriptome and epigenome, with minimal lineage priming. Widespread RNA polymerase 2 pausing may provide a mechanism for efficient activation of genes upon appropriate stimuli, turning the cells from a naïve to a primed state.

Primed pluripotent stem cell lines - termed epiblast stem cells (EpiSCs) - have been established from the epiblast of the postimplantation mouse blastocyst (Brons et al., 2007; Tesar et al., 2007) and by conversion of murine ES cells in vitro (Guo et al., 2009). Similarities between EpiSCs and ES cells include expression of the core pluripotency factors (Oct4, Sox2 and Nanog) as well as the ability to form teratomas. However, EpiSCs have distinct signaling requirements (FGF/Activin rather than LIF) and do not form chimeras, indicating that they are developmentally restricted compared to the naïve stem cells. The molecular control of transition from a naïve to a primed state remains elusive. Derk ten Berge (Erasmus Medical Center, Netherlands) focused on the role of Wnt proteins in this process. He showed that Wnt signals are essential self-renewal factors for ES cells, involved in inhibiting the differentiation of ES cells to EpiSCs. When used with LIF, Wnt proteins support self-renewal of germline-competent ES cells and even allow derivation of ES cells from non-permissive strains of mice (ten Berge et al., 2011).

Bertrand Pain's (INSERM-Lyon, France) group generated Epi-like cells from chicken embryos and performed comparative transcription analyses with chicken ES cells to ascertain expression patterns that define naïve and primed states. Chicken Epi-like stem cells, like mouse EpiSCs, are grown in the presence of Activin and FGF, and thus display similar growth factor requirements to human ES cells. Intra- and inter-species investigation of the existence of naïve and primed ES cell states are beginning to uncover evolutionary conserved and species-specific mechanisms that operate during development. Given the similarity in growth factor requirements, it would also be interesting to see whether chicken Epi-like stem cells exhibit similar sensitivity to dissociation-induced death underlying the lower cloning efficiency of mouse EpiSCs and human ES cells.

Poor survival of human ES cells is hindering their efficient expansion, and creates a selection pressure that may lead to the generation of variants harboring advantageous genetic changes which can overtake the culture (Amps et al., 2011; Baker et al., 2007; Draper et al., 2004). Hence, identifying the culture conditions that alleviate this obstacle remains a major focus in human ES cell research. This issue was touched upon by Martin Pera (University of Melbourne) who discussed the signalling networks required for maintenance of human ES cells. By concentrating on mechanisms that promote human ES cell survival, e.g. the use of small molecules and/or the maintenance of cell-cell contact, Prof. Pera believed that cell expansion on a therapeutic level could be achieved without the cells undergoing genetic changes which may influence their differentiation capacity. Another important aspect to consider when culturing human ES cells is their growth substrate. This was the focus of work undertaken by Loriana Vitillo (University of Manchester, UK) who discussed the molecular pathways that underlie fibronectin regulation of human ES cell survival. Interaction of cells with the extracellular matrix occurs through integrins which results in the activation of several focal adhesion-associated proteins, including focal adhesion kinase (FAK). As a key mediator of integrin signaling, FAK interacts with several signaling pathways, including a pro-survival phosphatidyl 3-kinase (PI3K) pathway. Indeed, Vitillo showed that FAK inhibition by selective inhibitors increased apoptosis of human ES cells, indicating a role of FAK in cell survival. Resolving the molecular signaling governing human ES cell death versus survival in vitro will inform the formulation of optimal culture conditions for robust maintenance of undifferentiated human ES cells.

Epigenetic characteristics - Since ES cells are the source of all cell types within the body, maintaining the genomic integrity of these cells would seem an evolutionary pre-requisite. Indeed, it has been known since the late 1970's that ES and EC cells can protect their genome by epigenetically silencing foreign DNA, particularly retroviral elements. However, the proteins involved in this silencing have only been recently revealed. In 2007, Wolf 
and Goff were able to show that TRIM28 forms part of a complex at the Pro ${ }^{\text {tRNA }}$ binding site (PBS) which can mediate retroviral silencing (Wolf and Goff, 2007). TRIM28 is directed to the DNA by Kruppel-associated box zinc finger (KRAB-ZNF) proteins, where it recruits a complex of proteins including histone deacetylases (HDAC) and methyltransferases (particularly SETDB1) involved in epigenetic modification. This key action of TRIM28 may explain its early expression in the embryo, though Barbara Knowles (IMB, Singapore) detailed a wider role for this protein. The work described involved the knockout of maternal TRIM28, which resulted in a high incidence of postimplantation lethality. Those pups which did survive were notably different, despite having the same genome, suggesting TRIM28 was an important epigenetic controller. Microarray studies provided further evidence of this, with problems found in regulating expression of the imprinted gene IGF2. Hence, it appears that the maternal TRIM28 complex may have far-reaching actions as a guardian of the epigenome during the early stages of development. An irregularity in epigenetic control of key pathways may pre-dispose ES cells to further changes, so Prof. Knowles suggested that occult epigenetic abnormalities may underlie the more obvious chromosomal changes observed in ES cells.

Utilising ES and EC cells to study epigenetic mechanisms during development was also discussed by Philip Avner (Institut Pasteur, France). Prof. Avner was particularly interested in the process of $\mathrm{X}$-inactivation, described as an epigenetic paradigm specific for mammals. Physical evidence for $X$-inactivation had been indirectly observed as early as 1949, with Barr describing the 'Barr body', which represented the condensed, inactive, X-chromosome (Barr and Bertram, 1949). Twelve years later, Mary Lyon first suggested this as an embryonic event, which was then propagated throughout the organism (Lyon, 1961). Fitting for this meeting though, was the fact that no in vitromodel existed for this process before the derivation of EC cell lines. Using a female teratocarcinoma cell line, Gail Martin (Martin et al., 1978) revealed X-chromosome inactivation during differentiation, a finding later confirmed in mouse ES cells. However, it should be noted that this is considered the second 'random' wave of X-inactivation. The initial X-inactivation is termed 'imprinted', and involves inactivation of the paternally-inherited $X$ chromosome during initial specification of the extra-embryonic tissues (Takagi and Sasaki, 1975). Imprinted inactivation has also been observed in vitro using XEN and TS cells, though surprisingly the acquisition of polycomb proteins varied between these two extra-embryonic lineages (Kunath et al., 2005).

During his lecture Prof. Avner outlined the machinery that controlled $\mathrm{X}$-inactivation, and related this process to cellular state. $\mathrm{X}$ inactivation is mediated by $X$-inactivation centre (Xic), a 600-1,200 $\mathrm{kb}$ stretch of DNA containing those genes which can silence the entire X chromosome. Whilst the Xic comprises a number of genes, capable of complex interaction, the best characterised player is Xist. Xist is a non-coding RNA which, prior to inactivation, coats chromosomal DNA and begins the cascade of events which conclude in the irreversible epigenetic silencing of the X-chromosome (Avner and Heard, 2001). These events involve the loss of euchromatic marks, the recruitment of polycomb proteins PRC1 (de Napoles et al., 2004) and PRC2 (Okamoto et al., 2004), and the establishment of heterochromatic domains. Genes capable of controlling Xist are then of obvious importance, and perhaps the other most notable gene in the Xic is Tsix, which is able to repress Xist. These two genes seem to be crucial in maintaining $X$-inactivation in the pluripotent state, since OCT4, NANOG and SOX2 have been shown to prevent Xist upregulation (Navarro et al., 2008), whereas REX1, KLF4 and C-MYC activate Tsix (Navarro et al., 2010).

Whilst there has been much progress made in elucidating the regulation of $\mathrm{X}$-inactivation, Prof. Avner was still able to raise a number of questions within his talk. One of the early observations in the field was that, although it is well accepted that cells inactivate the $\mathrm{X}$ chromosome during differentiation, this does not occur in all cells. The data from mouse EC cells reveals that only $\sim 60 \%$ of cells in culture activate Xist upon differentiation, and this is also true for mouse ES cells. Whether this is intrinsic to some cells, or merely stochastic, has yet to be determined, though is doubtless important when one considers that $X$-inactivation status is deemed one of the critical measures the 'true' ES cells.

Taking non-coding RNAs from Xist to the present was Alla Sigova (Whitehead Institute, USA), who was keen to understand the role these molecules play in cell fate decisions. Dr Sigova's work began with a screen of mouse ES cell specific non-coding (nc) RNA, which identified 195 candidates. Of these candidates, ncZMYND8 stood out since it was regulated by OCT4. Further interrogation showed that ncZMYND8 was located upstream of the ZMYND8 gene, encoding a zinc finger protein with a complex role in maintaining pluripotency. Although only expressed at low levels, the up- or down-regulation of ZMYND8 was capable of inducing differentiation in ES cells. Such dosage dependent effects are becoming better recognised in stem cells, and provide a further measure through which cellular state can be controlled.

\section{Relationship of embryonic stem (ES) cells in vitro to embryo development}

A recurring theme throughout the meeting was the question about the relationship of ES cells to their in vivo counterparts. Are ES cells a culture artifact or can we relate them to specific cells of the early embryo? Mouse embryonic development starts by formation of a zygote as a result of the oocyte fertilization by the sperm. After several rounds of cell divisions, the first segregation event occurs in the embryo, giving rise to trophectoderm and the inner cell mass (ICM). ICM cells consequently segregate into the hypoblast (the primitive endoderm) and the epiblast (primitive ectoderm). The hypoblast and epiblast are morphologically and molecularly distinct, with hypoblast expressing Gata6 and Gata4 transcription factors and epiblast expressing Nanog (Chambers et al., 2003; Chazaud et al., 2006). Whereas the trophectoderm and the hypoblast give rise to the extraembryonic tissues, the epiblast harbours pluripotent cells that develop into the embryo proper. Janet Rossant (Hospital for Sick Children, Toronto,Canada) discussed the plasticity of the cells in the early embryo and the mechanisms of lineage commitment. Although ICM cells of a $3.5 \mathrm{dpc}$ mouse embryo present a complex mosaic of cells, with a heterogeneous expression of Nanog and Gata6, the fate of these cells is not yet fully restricted. FGF/MAP kinase signal was highlighted as pivotal in determining their fate. Depletion of FGF/MAP kinase signal gave rise to Nanog-positive cells only, whereas all the cells of the ICM became Gata6-positive when exposed to excessive FGF signal (Yamanaka et al., 2010). Similarly, that the cells of the ICM can be heavily biased towards an epiblastic rather than hypoblastic fate by culturing mouse embryos in 2i media (Nichols et al., 2009) was further discussed in the talk by Austin Smith (University of 
Cambridge, UK). The two compounds also promoted self-renewal of mouse ES cells in vitro, indicating common signaling mechanisms in mouse ES cells and the early epiblast. Although Brook and Gardner 's microdissection experiments (Brook and Gardner, 1997) clearly demonstrated that epiblast is the source of ES cells, and that single epiblast cells from a $4.5 \mathrm{dpc}$ embryo can give rise to ES cells, the notion was that only a minor fraction of epiblast cells can generate ES cells. It is now apparent that the culture conditions modulate this ability as the $2 \mathrm{i}$ medium supplemented with LIF allows a higher number of ES cell clones to be isolated from an embryo (Nichols et al., 2009). Interestingly, although human blastocysts show non-overlapping expression of NANOG and GATA4, similar to mouse embryos, downregulation of FGF signaling does not affect human hypoblast formation (Roode et al., 2012).

Anestis Tsakiridis (University of Edinburgh, UK) continued this discussion by presenting work addressing the timing of cessation of pluripotency in vivo. Pluripotency of cells from different stages of mouse development was assessed by their ability to form teratocarcinomas and give rise to epiblast stem cells (EpiSCs). This work elegantly showed that the loss of pluripotency in vivo occurs around the onset of somitogenesis. The question that followed was what molecular changes underlie the loss of pluripotency? The reduction in Oct4 levels seems like a plausible candidate as ectopic Oct4 expression in somitogenesis-stage cells resulted in Nanog reactivation and allowed teratocarcinoma formation as well as derivation of EpiSC. This is mediated at the molecular level by re-opening of chromatin in regulatory regions of Oct4 and Nanog.

\section{Stem cell and stem cell states}

The embryonic stage that mouse ES cells, mouse EpiSC, and human ES cells represent, and their respective potencies, is something of a hang-up for the field at present. Indeed, this issue was addressed by many speakers, both in their lectures and the discussions that followed. In the case of mouse ES cells, the most rigorous test of ES cell pluripotency is a tetraploid complementation test, which involves fusing the blastomeres of a two-cell stage embryo and aggregating the resulting one-cell tetraploid embryo with ES cells (Nagy et al., 1990). The result of this should be an animal, in which the ES cells can be shown to contribute to all somatic lineages and also the germ line. For obvious reasons this is not possible for human ES or iPS cells, and hence surrogate tests e.g. teratoma formation, are sought. However, that human ES cells cannot satisfy mouse ES cell tests of pluripotency does not necessarily disqualify these cells from pluripotent status. Through various differentiation protocols, human ES cells have been shown capable of differentiation towards all 3 germ layers, and also germ cells themselves. Further, differentiation towards trophoblast has been achieved, which is not possible with mouse ES cells, and hints at speciation differences or that human ES cells derive from an earlier stage of embryonic development.

A more common conception however, is that human ES cells are derived from a developmental stage resembling the mouse post-implantation epiblast. This is based largely on the similarity of human ES and mouse EpiSC, both in terms of epi/genetic characteristics and signalling requirements. The genetic profiles of human ES and mouse EpiSC suggest that these cells are in a 'primed' state, expressing markers of pluripotency yet also differentiation. However, such analyses are invariably performed at a population level, and do not account for the heterogeneity present within the cultures. The propensity of ES cells to spontaneously differentiate results in heterogeneous cultures, comprising both undifferentiated stem cells as well as their differentiated progeny. In addition to heterogeneity due to differentiation, it is becoming increasingly evident that the undifferentiated stem cells themselves are not all equal but instead exist in distinct states. These states are interchangeable but individually they may bias the cell fate. Violetta Karwacki-Neisius (University of Edinburgh, UK) explored the source and functional significance of heterogeneity in mouse ES cells, focusing on the role of Nanog-Oct4 interactions. Nanog is expressed in a heterogeneous manner in ES cell cultures, and the level of Nanog expression is inversely correlated with the propensity of a stem cell to differentiate (Chambers et al., 2007). KarwackiNeisius showed that the homogeneous expression of Nanog can be achieved by reducing the Oct4 to around half of the wild-type level. A functional consequence of this is delayed differentiation of ES cells. Nanog mosaicism is again restored by raising the Oct4 level of expression and this also rescues delayed differentiation. These findings suggest a feedback control mechanism between Oct4 and Nanog and offer insight into hierarchies of transcription factor heterogeneity.

Talks presented at this meeting indicated that fascinating questions regarding heterogeneity, stem cell fates and the evolutionary changes that may have led to inter-species differences in development are poised for transformational gains in the near future. As Janet Rossant concluded in her talk, for the progress in this area to take place we need: (i) better understanding of human development through experimental study, (ii) more careful comparative analyses of different human and mouse pluripotent stem cell lines, and (iii) better assays for assessing pluripotency.

\section{Int. J. Dev. Biol. poster awards}

The ongoing efforts to uncover some of the questions aforementioned came into view through talks and posters by junior scientists in the field. Poster prizes sponsored by The International Journal of Developmental Biology (Int. J. Dev. Biol.) were awarded to the following young researchers:

${ }_{1 \text { st }}$ prize: M. Afanassieff. Contrasting features of embryonic and induced pluripotent stem cells in rabbit.

$2^{\text {nd }}$ prize: A. Sinha. The OCIA domain protein Asrij is required to maintain embryonic stem cell pluripotency.

$3^{\text {rd }}$ prize: Pierre-Yves Bourillot. KLF4 and KLF5 play specific roles in the inhibition of ES cell differentiation into extra-embryonic endoderm and mesendoderm.

Winners were offered complimentary Int. J. Dev. Biol. subscriptions and publishing packages.

\section{Summary}

The journey home from Cardiff provided plenty of time for reflection, and a chance to appreciate the great distance the field has covered since pluripotent embryonal carcinoma cells were described in germ cell tumours. However, it was also obvious how far this area of research has yet to travel. Despite gathering together some of the most influential thinkers, no agreement could be reached as to which range of cells were truly pluripotent, and what stage of embryonic development the different stem cell types 
represented. The confounding effects of speciation and heterogeneity still have the potential to cloud our vision, yet the illuminating science presented at this meeting suggests that a clearer picture will soon emerge.

\section{Acknowledgements \\ Those present at the meeting would like to thank Abcam for organizing this event, and for the financial support that they provided.}

\section{Ivana Barbaric and Neil J. Harrison}

Centre for Stem Cell Biology and the Department of Biomedical Science, University of Sheffield, Western Bank, Sheffield, UK

KEY WORDS: embryonal carcinoma, embryonic stem cell, pluripotency, differentiation

\section{References}

AMPS K., ANDREWS P.W., ANYFANTIS G., ARMSTRONG L., AVERY S., BAHARVAND H., BAKER J., BAKER D., MUNOZ M.B., BEIL S., , et al., (2011). Screening ethnically diverse human embryonic stem cells identifies a chromosome 20 minimal amplicon conferring growth advantage. Nat Biotechnol.

ANDREWS P.W. (2002). From teratocarcinomas to embryonic stem cells. Philos Trans $R$ Soc Lond B Biol Sci 357: 405-417.

ARTZT K., DUBOIS P., BENNETT D., CONDAMINE H., BABINET C., JACOB F. (1973). Surface antigens common to mouse cleavage embryos and primitive teratocarcinoma cells in culture. Proc Natl Acad Sci USA 70: 2988-2992.

AVNER P., HEARD E. (2001). X-chromosome inactivation: counting, choice and initiation. Nat Rev Genet 2: 59-67.

BAKER D.E., HARRISON N.J., MALTBY E., SMITH K., MOORE H.D., SHAW P.J., HEATH P.R., HOLDEN H., ANDREWS P.W. (2007). Adaptation to culture of human embryonic stem cells and oncogenesis in vivo. Nat Biotechnol 25: 207-215.

BARR M.L., BERTRAM E.G. (1949). A morphological distinction between neurones of the male and female, and the behaviour of the nucleolar satellite during accelerated nucleoprotein synthesis. Nature 163: 676.

BRINSTER R.L. (1974). The effect of cells transferred into the mouse blastocyst on subsequent development. J Exp Med 140: 1049-1056.

BRONS I.G., SMITHERS L.E., TROTTER M.W., RUGG-GUNN P., SUN B., CHUVA DE SOUSALOPES S.M., HOWLETT S.K., CLARKSONA., AHRLUND-RICHTER L., PEDERSEN R.A., VALLIER L. (2007). Derivation of pluripotent epiblast stem cells from mammalian embryos. Nature 448: 191-195.

BROOK F.A., GARDNER R.L. (1997). The origin and efficient derivation of embryonic stem cells in the mouse. Proc Natl Acad Sci USA 94: 5709-5712.

CHAMBERS I., COLBY D., ROBERTSON M., NICHOLS J., LEE S., TWEEDIE S., SMITHA. (2003). Functional expression cloning of Nanog, a pluripotency sustaining factor in embryonic stem cells. Cell 113: 643-655.

CHAMBERS I., SILVA J., COLBY D., NICHOLS J., NIJMEIJER B., ROBERTSON M., VRANA J., JONES K., GROTEWOLD L., SMITH A. (2007). Nanog safeguards pluripotency and mediates germline development. Nature 450: 1230-1234.

CHAZAUD C., YAMANAKA Y., PAWSON T., ROSSANT J. (2006). Early lineage segregation between epiblast and primitive endoderm in mouse blastocysts through the Grb2-MAPK pathway. Dev Cell 10: 615-624.

DAMJANOV I., ANDREWS P.W. (2007). The terminology of teratocarcinomas and teratomas. Nat Biotechnol 25: 1212; discussion 1212.

DE NAPOLES M., MERMOUD J.E., WAKAO R., TANG Y.A., ENDOH M., APPANAH R., NESTEROVAT.B., SILVAJ., OTTEA.P., VIDALM., KOSEKIH., BROCKDORFF N. (2004). Polycomb group proteins Ring1A/B link ubiquitylation of histone H2A to heritable gene silencing and $X$ inactivation. Dev Cell 7: 663-676.

DRAPER J.S., PIGOTT C., THOMSON J.A., ANDREWS P.W. (2002). Surface antigens of human embryonic stem cells: changes upon differentiation in culture. J Anat 200: 249-258.

DRAPER J.S., SMITH K., GOKHALE P., MOORE H.D., MALTBY E., JOHNSON J., MEISNER L., ZWAKA T.P., THOMSON J.A., ANDREWS P.W. (2004). Recurrent gain of chromosomes $17 \mathrm{q}$ and 12 in cultured human embryonic stem cells. Nat Biotechnol 22: 53-54.

EVANS M.J. (1972). The isolation and properties of a clonal tissue culture strain of pluripotent mouse teratoma cells. J Embryol Exp Morphol 28: 163-176.

EVANS M.J., KAUFMAN M.H. (1981). Establishment in culture of pluripotential cells from mouse embryos. Nature 292: 154-156.

FAWCETT D.W. (1950). Bilateral ovarian teratomas in a mouse. Cancer Res 10: 705-707.

GARDNER R.L. (1968). Mouse chimeras obtained by the injection of cells into the blastocyst. Nature 220: 596-597.

GOREA., LIZ., FUNG H.L., YOUNG J.E., AGARWALS., ANTOSIEWICZ-BOURGET J., CANTO I., GIORGETTI A., ISRAEL M.A., KISKINIS E., LEE J.H. et al. (2011). Somatic coding mutations in human induced pluripotent stem cells. Nature 471: 63-67.

GUO G., YANG J., NICHOLS J., HALL J.S., EYRES I., MANSFIELD W., SMITH A. (2009). Klf4 reverts developmentally programmed restriction of ground state pluripotency. Development 136: 1063-1069.

HOLDEN S., BERNARD O., ARTZT K., WHITMORE W.F., JR., BENNETT D. (1977). Human and mouse embryonal carcinoma cells in culture share an embryonic antigen (F9). Nature 270: 518-520.

JAKOB H., BOON T., GAILLARD J., NICOLAS J., JACOB F. (1973). Teratocarcinoma of the mouse: isolation, culture and properties of pluripotential cells. Ann Microbiol (Paris) 124: 269-282.

JOHNSON M.H., MARO B., TAKEICHI M. (1986). The role of cell adhesion in the synchronization and orientation of polarization in 8-cell mouse blastomeres. $J$ Embryol Exp Morphol 93: 239-255.

KAHAN B.W., EPHRUSSI B. (1970). Developmental potentialities of clonal in vitro cultures of mouse testicular teratoma. J Natl Cancer Inst 44: 1015-1036.

KLEINSMITH L.J., PIERCE G.B., JR. (1964). Multipotentiality of Single Embryonal Carcinoma Cells. Cancer Res 24: 1544-1551.

KUNATH T., ARNAUD D., UY G.D., OKAMOTO I., CHUREAU C., YAMANAKA Y., HEARD E., GARDNER R.L., AVNER P., ROSSANT J. (2005). Imprinted $X$-inactivation in extra-embryonic endoderm cell lines from mouse blastocysts. Development 132: 1649-1661.

LEITCH H.G., BLAIR K., MANSFIELD W., AYETEY H., HUMPHREYS P., NICHOLS J., SURANI M.A., SMITH A. (2010). Embryonic germ cells from mice and rats exhibit properties consistent with a generic pluripotent ground state. Development 137: 2279-87.

LYON M.F. (1961). Gene action in the X-chromosome of the mouse (Mus musculus L.). Nature 190: 372-373.

MANI S.A., GUO W., LIAO M.J., EATON E.N., AYYANAN A., ZHOU A.Y., BROOKS M., REINHARD F., ZHANG C.C., SHIPITSIN M., CAMPBELL L.L., POLYAK K., BRISKEN C., YANG J., WEINBERG R.A. (2008). The epithelial-mesenchymal transition generates cells with properties of stem cells. Cell 133: 704-715.

MARTIN G.R. (1981). Isolation of a pluripotent cell line from early mouse embryos cultured in medium conditioned by teratocarcinoma stem cells. Proc Natl Acad Sci USA 78: 7634-7638.

MARTIN G.R., EVANS M.J. (1974). The morphology and growth of a pluripotent teratocarcinoma cell line and its derivatives in tissue culture. Cell 2: 163-172.

MARTIN G.R., EVANS M.J. (1975). Differentiation of clonal lines of teratocarcinoma cells: formation of embryoid bodies in vitro. Proc NatlAcad SciUSA72: 1441-1445.

MARTIN G.R., EPSTEIN C.J., TRAVIS B., TUCKER G., YATZIV S., MARTIN D.W., JR., CLIFTS., COHENS. (1978). X-chromosome inactivation during differentiation of female teratocarcinoma stem cells in vitro. Nature 271: 329-333.

MATSUI Y., ZSEBO K., HOGAN B.L. (1992). Derivation of pluripotential embryonic stem cells from murine primordial germ cells in culture. Cell 70: 841-847.

MAYSHAR Y., BEN-DAVID U., LAVON N., BIANCOTTI J.C., YAKIR B., CLARK A.T., PLATH K., LOWRY W.E., BENVENISTY N. (2010). Identification and classification of chromosomal aberrations in human induced pluripotent stem cells. Cell Stem Cell 7: 521-31.

MINTZ B. (1962). Formation of Genotypically Mosaic Mouse Embryos. American Zoologist 2: 432-432.

NAGYA., GOCZA E., DIAZ E.M., PRIDEAUX V.R., IVANYIE., MARKKULA M., ROSSANT J. (1990). Embryonic stem cells alone are able to support fetal development in the mouse. Development 110: 815-821. 
NAVARRO P., CHAMBERS I., KARWACKI-NEISIUS V., CHUREAU C., MOREY C., ROUGEULLE C., AVNER P. (2008). Molecular coupling of Xist regulation and pluripotency. Science 321: 1693-1695.

NAVARRO P., OLDFIELD A., LEGOUPI J., FESTUCCIA N., DUBOIS A., ATTIA M., SCHOORLEMMER J., ROUGEULLE C., CHAMBERS I., AVNER P. (2010). Molecular coupling of Tsix regulation and pluripotency. Nature 468: 457-460.

NICHOLS J., SILVA J., ROODE M., SMITH A. (2009). Suppression of Erk signalling promotes ground state pluripotency in the mouse embryo. Development 136: 3215-3222.

OKAMOTO I., OTTE A.P., ALLIS C.D., REINBERG D., HEARD E. (2004). Epigenetic dynamics of imprinted $X$ inactivation during early mouse development. Science 303: 644-649.

OOSTERHUIS J.W., LOOIJENGA L.H. (2005). Testicular germ-cell tumours in a broader perspective. Nat Rev Cancer 5: 210-222.

PARK J.I., VENTEICHER A.S., HONG J.Y., CHOI J., JUN S., SHKRELI M., CHANG W., MENG Z., CHEUNG P., Jl H. et al. (2009). Telomerase modulates Wnt signalling by association with target gene chromatin. Nature 460: 66-72.

RAJPERT-DE MEYTS E. (2006). Developmental model for the pathogenesis of testicular carcinoma in situ: genetic and environmental aspects. Hum Reprod Update 12: 303-323.

ROODE M., BLAIR K., SNELL P., ELDER K., MARCHANT S., SMITH A., NICHOLS J. (2012). Human hypoblast formation is not dependent on FGF signalling. Dev Biol 361: 358-363.

ROSENTHALM.D., WISHNOWR.M., SATO G.H. (1970). In vitrogrowth and differetiation of clonal populations of multipotential mouse clls derived from a transplantable testicular teratocarcinoma. J Natl Cancer Inst 44: 1001-14.

SKAKKEBAEKN.E. (1972). Possible carcinoma-in-situ of the testis. Lancet 2:516-517.

SMITHA.G., HEATH J.K., DONALDSON D.D., WONG G.G., MOREAU J., STAHLM., ROGERS D. (1988). Inhibition of pluripotential embryonic stem cell differentiation by purified polypeptides. Nature 336: 688-690.

SOLTER D., KNOWLES B.B. (1978). Monoclonal antibody defining a stage-specific mouse embryonic antigen (SSEA-1). Proc Natl Acad Sci USA 75: 5565-5569.

SOLTER D., SKREB N., DAMJANOV I. (1970). Extrauterine growth of mouse eggcylinders results in malignant teratoma. Nature 227: 503-504.

SONCIN F., MOHAMET L., ECKARDT D., RITSON S., EASTHAM A.M., BOBOLA N., RUSSELL A., DAVIES S., KEMLER R., MERRY C.L., WARD C.M. (2009). Abrogation of E-cadherin-mediated cell-cell contact in mouse embryonic stem cells results in reversible LIF-independent self-renewal. Stem Cells27:2069-2080.

STERN P., MARTIN G.R., EVANS M. (1975). Cell surface antigens of clonal teratocarcinoma cells at various stages of differentiation. Cell 6: 455-465.

STERN P.L., WILLISON K.R., LENNOX E., GALFRE G., MILSTEIN C., SECHER D., ZIEGLER A. (1978). Monoclonal antibodies as probes for differentiation and tumor-associated antigens: a Forssman specificity on teratocarcinoma stem cells. Cell 14: 775-783.
STEVENS L.C. (1967). Origin of testicular teratomas from primordial germ cells in mice. J Natl Cancer Inst 38: 549-552.

STEVENS L.C. (1968). The development of teratomas from intratesticular grafts of tubal mouse eggs. J Embryol Exp Morphol 20: 329-341.

STEVENS L.C., LITTLE C.C. (1954). Spontaneous Testicular Teratomas in an Inbred Strain of Mice. Proc Natl Acad Sci USA 40: 1080-1087.

STEVENS L.C., VARNUM D.S. (1974). The development of teratomas from parthenogenetically activated ovarian mouse eggs. Dev Biol 37: 369-380.

TAKAGI N., SASAKI M. (1975). Preferential inactivation of the paternally derived X chromosome in the extraembryonic membranes of the mouse. Nature 256:640-642.

TAKAHASHI K., TANABE K., OHNUKI M., NARITA M., ICHISAKA T., TOMODA K., YAMANAKA S. (2007). Induction of pluripotent stem cells from adult human fibroblasts by defined factors. Cell 131: 861-872.

TANG C., LEEA.S., VOLKMER J.P., SAHOO D., NAG D., MOSLEYA.R., INLAYM.A., ARDEHALI R., CHAVEZ S.L., PERA R.R., BEHR B., WU J.C., WEISSMAN I.L., DRUKKER M. (2011). An antibody against SSEA-5 glycan on human pluripotent stem cells enables removal of teratoma-forming cells. Nat Biotechnol29:829-834.

TARKOWSKI A.K. (1961). Mouse chimaeras developed from fused eggs. Nature 190: 857-860

TEN BERGE D., KUREK D., BLAUWKAMP T., KOOLE W., MAAS A., EROGLU E., SIU R.K., NUSSE R. (2011). Embryonic stem cells require Wnt proteins to prevent differentiation to epiblast stem cells. Nat Cell Biol 13: 1070-1075.

TESAR P.J., CHENOWETH J.G., BROOK F.A., DAVIES T.J., EVANS E.P., MACK D.L., GARDNER R.L., MCKAY R.D. (2007). New cell lines from mouse epiblast share defining features with human embryonic stem cells. Nature 448: 196-199.

THOMSONJ.A., ITSKOVITZ-ELDORJ., SHAPIRO S.S., WAKNITZM.A., SWIERGIEL J.J., MARSHALL V.S., JONES J.M. (1998). Embryonic stem cell lines derived from human blastocysts. Science 282: 1145-1147.

WOLF D., GOFF S.P. (2007). TRIM28 mediates primer binding site-targeted silencing of murine leukemia virus in embryonic cells. Cell 131: 46-57.

WRIGHT A., ANDREWS N., BARDSLEY K., NIELSEN J.E., AVERY K., PEWSEY E., JONES M., HARLEY D., NIELSEN A.R., MOORE H. et al. (2011). Mapping the stem cell state: eight novel human embryonic stem and embryonal carcinoma cell antibodies. Int J Androl 34:e175-187; discussion e187-e188.

YAMANAKA Y., LANNER F., ROSSANT J. (2010). FGF signal-dependent segregation of primitive endoderm and epiblast in the mouse blastocyst. Development 137: 715-724

YING Q.L., NICHOLS J., CHAMBERS I., SMITH A. (2003). BMP induction of Id proteins suppresses differentiation and sustains embryonic stem cell self-renewal in collaboration with STAT3. Cell 115: 281-292.

YING Q.L., WRAY J., NICHOLS J., BATLLE-MORERA L., DOBLE B., WOODGETT J., COHEN P., SMITH A. (2008). The ground state of embryonic stem cell selfrenewal. Nature 453: 519-523. 


\section{Further Related Reading, published previously in the Int. J. Dev. Biol.}

Patterning the nervous system through development and evolution Alain Ghysen, Christine Dambly-Chaudière and David W. Raible Int. J. Dev. Biol. (2010) 54: S1-S14

Stem Cells in Biology and Disease - ESTOOLS International Symposium Sergio Pistoi

Int. J. Dev. Biol. (2010) 54: 1399-1404

Faithful reprogramming to pluripotency in mammals - what does nuclear transfer teach us? Julien Maruotti, Alice Jouneau and Jean-Paul Renard

Int. J. Dev. Biol. (2010) 54: 1609-1621

Reprogramming cell fate to pluripotency: the decision-making signalling pathways Daniela Sanges and Maria-Pia Cosma

Int. J. Dev. Biol. (2010) 54: 1575-1587

Natural and artificial routes to pluripotency

Winfried H. Krueger, Lindsey C. Swanson, Borko Tanasijevic and Theodore P. Rasmussen Int. J. Dev. Biol. (2010) 54: 1545-1564

Pluripotency of bank vole embryonic cells depends on FGF2 and activin A signaling pathways

Aneta Suwinska, Andrzej K. Tarkowski and Maria A. Ciemerych

Int. J. Dev. Biol. (2010) 54: 113-124

Primordial germ cell biology at the beginning of the XXI Century Massimo De Felici

Int. J. Dev. Biol. (2009) 53: 891-894

Pluripotency and differentiation in embryos and stem cells - Pavia, 17-18 January 2008 James A. Adjaye, Anne G. Byskov, Jose B. Cibelli, Ruggero De Maria, Stephen Minger, Maurilio Sampaolesi, Giuseppe Testa, Catherine Verfaillie, Magdalena Zernicka-Goetz, Hans Schöler, Michele Boiani, Nicola Crosetto and Carlo A. Redi Int. J. Dev. Biol. (2008) 52: 801-809

5 yr ISI Impact Factor $(2010)=2.961$

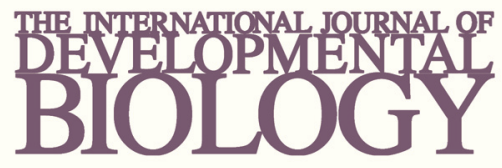

Volume 54 Nos. 6/7
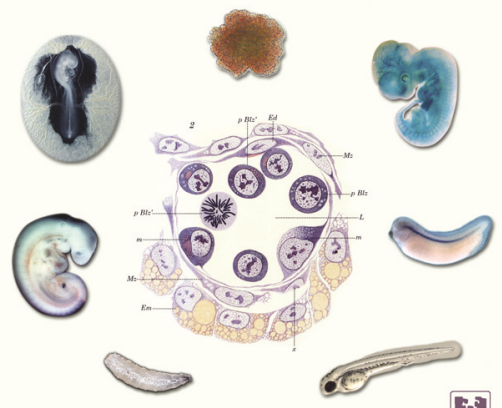

Developmental Hematopoiesis

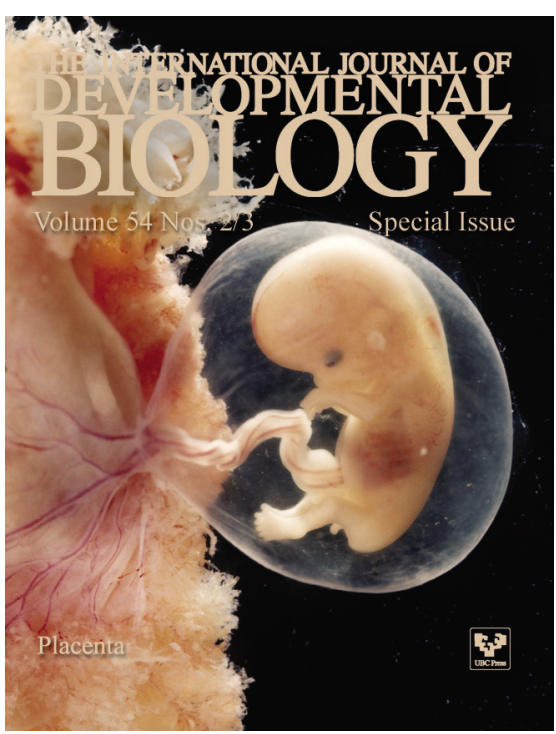

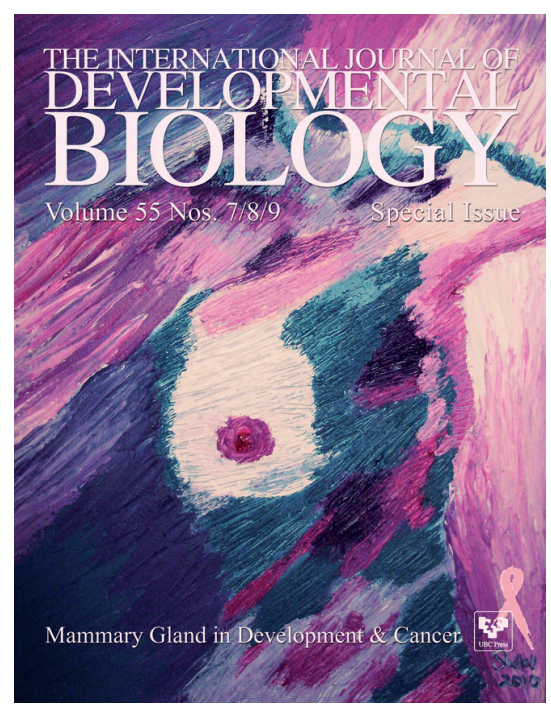

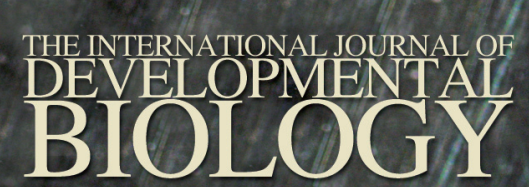

Volume 56 Nos. $1 / 2 / 3$

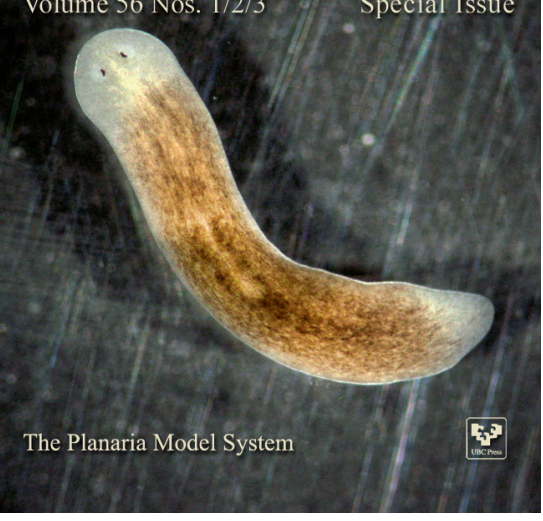

